\title{
Systemic Hypertension and Polycythemia in Tetralogy of Fallot
}

\author{
Isao Sakashita, M.D., Tetsunosuke Matsukawa, M.D., \\ Shigetaka Kasuya, M.D., Takeshi Ando, M.D., and \\ Ken-ichi Asano, M.D.
}

\begin{abstract}
SUMmaRY
In our series of 111 cases of tetralogy of Fallot, the result revealed that cases with high $\mathrm{Hb}$-content was accompanied more frequently by hypertension. However, their causes and effect relationship could not be clarified and more complicated mechanism was imagined to be acting.

From this series, these conditions of high $\mathrm{Hb}$-content, hypertension and positive urinary protein will be estimated to occur in a patient at about the age of 10 years with tetralogy of Fallot, but for surgical point of view, such conditions do not contraindicate primary corrective surgery for the disease. Palliative operations are also found to be preferable to improve these conditions. In patients of an advanced age with hypertension, careful examinations including renal biopsy will be helpfu l to make the final decision for surgery.
\end{abstract}

\section{Additional lndexing Words:}

Polycythemia Hypertension Blalock operation Corrective surgery Renal biopsy

WITH an increase in numbers of corrective surgery for tetralogy of Fallot, some difficulties on operative indication and technique have been occasionally experienced because of accompaniment of other cardiovascular abnormalities or pathologic conditions to the original disease. One of these indicates tetralogy of Fallot with systemic hypertension and clinical follow-up on this condition has rarely been performed. In this report, we present 4 patients with systemic hypertension who revealed interesting pre- and postoperative course following Blalock operation and/or corrective surgery.

\section{Materials}

In our Department, corrective surgery for tetralogy of Fallot has been done in 129 cases since 1965. Operative mortality was noted in 11 cases, indicating

\footnotetext{
From the Department of Thoracic and Cardiovascular Surgery, Niigata University School of Medicine, Niigata.

Received for publication February 26, 1973.
} 
Table I

\begin{tabular}{c|l|c}
\hline Group 1 & $\begin{array}{l}\text { Corrective surgery alone and post Blalock operation with unavailable } \\
\text { previous records }\end{array}$ & 85 cases \\
\hline Group 2 & Blalock operation followed by corrective surgery & 26 cases
\end{tabular}

$8.5 \%$ of its rate. Late death was found in 7 cases. In this report, 111 cases, consisting of 85 cases with respective unavailable records following the previous Blalock operation and corrective surgery alone, and 26 cases which Blalock operation was followed by corrective surgery, were investigated (Table I).

As standard values for $\mathrm{Hb}$-content, blood pressure and the presence of urinary protein, respective $18 \mathrm{Gm} / 100 \mathrm{ml}, 140 \mathrm{mmHg}$ (systolic) and/or $90 \mathrm{mmHg}$ (diastolic), and reactions of Albustix were used.

\section{Results}

In group 1 of 85 cases, 30 cases revealed the value more than $18 \mathrm{Gm} /$ $100 \mathrm{ml}$ of $\mathrm{Hb}$-content and in these, 8 cases $(25 \%$ ) had systemic hypertension. Two cases with hypertension showed the presence of urinary protein. On the other hand, out of the remaining 55 cases with Hb-content less than 18 $\mathrm{Gm} / 100 \mathrm{ml}, 4$ cases $(7 \%$ ) exhibited hypertension, however, no case of positive urinary protein was detected (Table II).

In group 2, before Blalock operation, 16 of 26 cases (62\%) showed $\mathrm{Hb}$ content of more than $18 \mathrm{Gm} / 100 \mathrm{ml}$. Five patients with high $\mathrm{Hb}$-content revealed hypertension and of which, 2 cases were also postitive in urinary protein (Table III). Following Blalock operation, 10 out of 16 cases with high Hb-content improved below a standard value. Five patients accompanied by hypertension were also ameliorated. However, positive urinary protein in 2 cases continued thereafter. Hb-content in all cases decreased below $18 \mathrm{Gm} /$ $100 \mathrm{ml}$ after corrective surgery, but urinary protein in only 1 case remained unchanged (Table IV). The distribution of the age of patients with high

Table II. Group 1

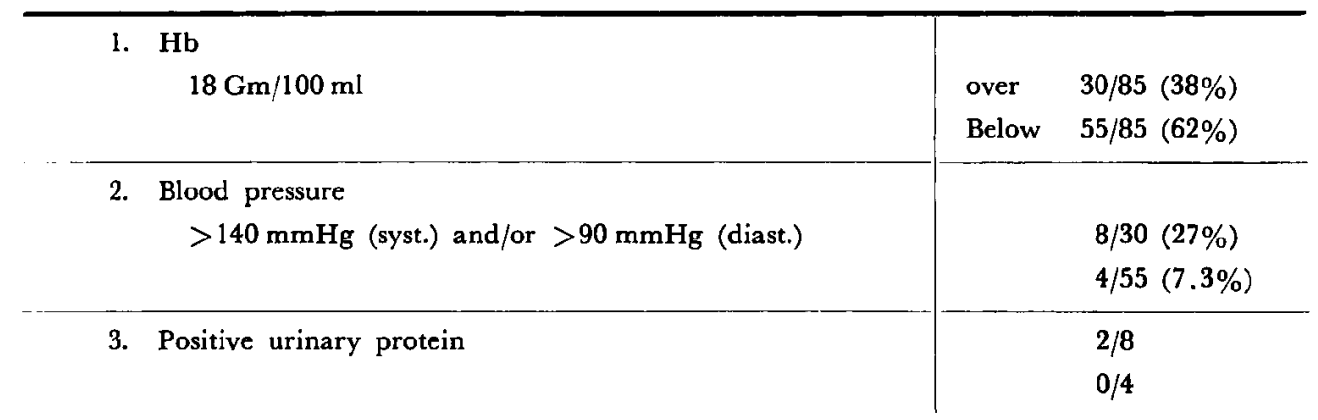


$\mathrm{Hb}$-content, hypertension and positive urinary protein in the group 1 and 2 ranged from 13 to 30 years. Operative death was noted in 4 of 8 cases with high Hb-content and hypertension in group 1 , but no death in group 2 (Tables $\mathrm{V}$ and $\mathrm{VI}$ ).

Table III. Group 2 (Before Blalock operation)

\begin{tabular}{|c|c|c|}
\hline $\begin{array}{l}\text { 1. } \mathrm{Hb} \\
18 \mathrm{Gm} / 100 \mathrm{ml}\end{array}$ & $\begin{array}{l}\text { over } \\
\text { below }\end{array}$ & $\begin{array}{l}16 / 26(62 \%) \\
10 / 26(38 \%)\end{array}$ \\
\hline $\begin{array}{l}\text { 2. Blood pressure } \\
>140 \mathrm{mmHg} \text { (syst.) and/or }>90 \mathrm{mmHg} \text { (diast.) }\end{array}$ & & $\begin{array}{l}5 / 16(31 \%) \\
0 / 10\end{array}$ \\
\hline 3. Positive urinary protein & & $\begin{array}{l}2 / 5 \\
0 / 0\end{array}$ \\
\hline
\end{tabular}

Table IV. Group 2 (After Blalock operation)

\begin{tabular}{|c|c|c|c|}
\hline & $\begin{array}{l}\mathrm{Hb} \\
\qquad 18 \mathrm{Gm} / 100 \mathrm{ml}\end{array}$ & $\begin{array}{l}\text { over } \\
\text { below }\end{array}$ & $\begin{array}{r}6 / 16 \\
10 / 16\end{array}$ \\
\hline 2. & $\begin{array}{l}\text { Blood Pressure } \\
\qquad>140 \mathrm{mmHg} \text { (syst.) and/or }>90 \mathrm{mmHg} \text { (diast.) }\end{array}$ & & $0 / 5$ \\
\hline & Positive urinary protein & & $2 / 5$ \\
\hline
\end{tabular}

Table V. Group 1: 85 cases

\begin{tabular}{|c|c|c|c|c|c|c|c|}
\hline 1. $\mathrm{Hb}$ & \multicolumn{4}{|c|}{$\begin{array}{c}>18 \mathrm{Gm} / 100 \mathrm{ml} \\
30 / 85 \\
\end{array}$} & \multicolumn{3}{|c|}{$\begin{array}{c}<18 \mathrm{Gm} / 100 \mathrm{ml} \\
55 / 85\end{array}$} \\
\hline 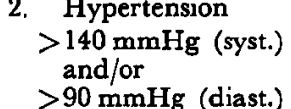 & & & & & & & $\left(\frac{1}{51 / 55}\right.$ \\
\hline 3. Urinary protein & $\stackrel{(+}{2 / 8}$ & $(-1)$ & $(-$ & $\stackrel{(-)}{22 / 22}$ & $\stackrel{(+)}{+}$ & $\left(\frac{1}{4 / 4}\right)$ & $\begin{array}{l}\left(\begin{array}{l}1 \\
+\end{array}\right) \\
2 / 51\end{array}$ \\
\hline 4. Operative death & 2 & 2 & (i) & (5) & 0 & 0 & (1) \\
\hline
\end{tabular}

Table VI. Group 2: 26 cases (Before Blalock operation)

\begin{tabular}{|c|c|c|c|c|c|}
\hline $\begin{array}{ll}\text { 1. } \mathrm{Hb} \\
\text { 2. Hypertension }\end{array}$ & \multicolumn{3}{|c|}{$>18 \mathrm{Gm} / 100 \mathrm{ml}$} & \multicolumn{2}{|c|}{$<18 \mathrm{Gm} / 100 \mathrm{ml}$} \\
\hline $\begin{array}{l}>140 \mathrm{mmHg} \text { (syst.) } \\
\text { and/or } \\
>90 \mathrm{mmHg} \text { (diast.) }\end{array}$ & & & $\left(\frac{1}{-1 / 6}\right)$ & $\begin{array}{c}(++ \\
0 \\
1\end{array}$ & $\left(\frac{1}{)}\right)$ \\
\hline 3. Urinary protein & $\begin{array}{l}(+) \\
2 / 5\end{array}$ & $\left(\frac{1}{3 / 5}\right)$ & $\begin{array}{c}(-)) \\
10 / 11\end{array}$ & $\left(\begin{array}{c}+ \\
0\end{array}\right)$ & $\left(\begin{array}{c}1 \\
0\end{array}\right)$ \\
\hline 4. Operative death & 0 & 0 & 0 & o & 1 \\
\hline
\end{tabular}


Effects of respective Blalock operation, corrective surgery following Blalock operation and primary corrective operation on cases with systemic hypertension have been evaluated including autopsy findings of 1 case.

Case: 1 26-year-old female.

Her delivery was normal, however, she was found to have heart disease at the medical examination for an unweaned child, at which time her growth was markedly retarded. Thereafter, her exercise tolerance gradually improved through the days of an elementary and a junior high school and at the age of 17, she was diagnosed

Table VII. Case 1:26-year-old female

\begin{tabular}{l|c|c|c}
\hline & $\begin{array}{c}\text { First admission } \\
\text { (Left Blalock op. })\end{array}$ & $\begin{array}{c}\text { Second admission } \\
\text { (Corrective surg. }\end{array}$ & At discharge \\
\hline $\begin{array}{l}\text { Blood pressure }(\mathrm{mmHg}) \\
\text { Hematologic study }\end{array}$ & $190-128$ & $134-92$ & $105-83$ \\
RBC $\left(\times 10^{4}\right)$ & 749 & 607 & 443 \\
Hb $(\mathrm{Gm} / 100 \mathrm{ml})$ & 17.1 & 17.6 & 14 \\
Hct $(\%)$ & 60 & 59.5 & 49 \\
WBC & 3,700 & 7,400 & 600 \\
Urinalysis & $(+)$ & $(-)$ & $(-)$ \\
Alubstix for albumin & Normal & Normal & \\
Sediment & $(-)$ & & \\
Other tests & $(-)$ & & \\
Urinary VMA & & & \\
Regitin test & & &
\end{tabular}

26 YEARS $q$

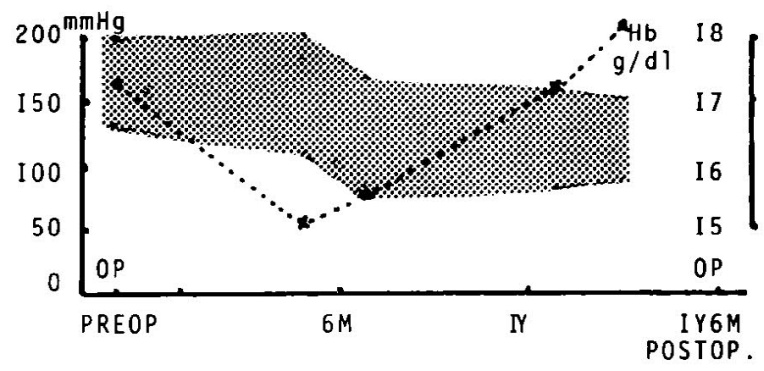

I2 YEARS $\delta$

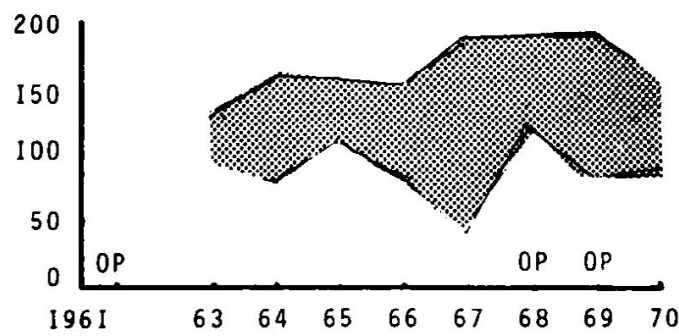

Fig. 1 
to be tetralogy of Fallot and adviced to have Blalock operation. At the lst admission to the University Hospital, the patient was cyanotic and revealed clubbed fingers.

On auscultation, grade 4 systolic murmur was detected in the 3rd intercostal space along the left sternal border and also grade 4 systolic murmur was audible in the 2nd intercostal space along the right sternal border with thrill over the same area. ECG revealed electric axis of $105^{\circ}$ and RVH. In the chest X-ray film, bilateral old tuberculous lesions and normal peripheral pulmonary vascularities were noted. Results of various tests including blood pressure, hematologic study, urinalysis etc were summarized in the Table VII. In May, 1970, with an expectation to improve blood pressure, Blalock operation was performed on the left. The postoperative course of blood pressure and Hb-content is shown in Fig. 1. Blood pressure started to drop 6 months postoperatively and its value just before corrective surgery was $134-92 \mathrm{mmHg}$. On the other hand, $\mathrm{Hb}$-content gradually increased up to $17.6 \mathrm{Gm} / 100 \mathrm{ml}$ until corrective surgery following a temporary postoperative amelioration.

At the 2nd admission in November, 1970, corrective surgery was done and her postoperative course was uneventful in spite of minimal wound infection. Blood pressure 2 months after surgery was $120-70 \mathrm{mmHg}$.

\section{Comment:}

In this series, 5 cases including this one, blood pressure was improved following Blalock operation. However, no definite trend for high $\mathrm{Hb}$-content and positive urinary protein was obtained with surgery, and more ameliorations on these findings seemed to be achieved through corrective surgery.

Case 2: 12-year-old male.

The patient was noticed to be cyanotic shortly after birth, and pointed out to have congenital heart disease. At the age of 3 , he had Blalock operation on the left, resulting in marked improvement of cyanosis and clubbed fingers. However, he was noticed to have hypertension at about the age of 6 , and has been followed up at the outpatient clinic of Pediatrics of this University. His family history showed a hypertensive tendency on the father's side and his 2 younger siblings have been hypertensive for their ages.

At the lst admission to the hospital, he was acyanotic, and on ausculation, grade 5 systolic murmur was audible in the 3rd intercostal space along the left sternal border with thrill. Shunt murmur of Blalock anastomosis was also noticeable in the 2nd intercostal space on the left. Second sound was accentuated. EGG showed $+105^{\circ}$ of electric axis, and hypertrophy of the right atrium and ventricle. Cardiac shadow was characteristic to tetralogy of Fallot and peripheral pulmonary vascularities were also within normal limit on the chest film. Results of various tests are disclosed in the Table VIII.

Changes of blood pressure are disclosed in the lower part of Fig. 1. Because of a decrease of blood pressure following the previous Blalock operation performed in 1961, which would be suspective of the further desirable effect on blood pressure by Blalock operation on the opposite side, Blalock operation was carried out on the right in July of 1968.

At the 2nd admission in October, 1969, corrective surgery was performed despite continuous hypertension following the 2nd Blalock operation, because of no evidence of abnormal renal functions, and he was discharged on the 45 th postopera- 
Table VIII. Case 2: 12-pear-old male

\begin{tabular}{|c|c|c|c|}
\hline & $\begin{array}{c}\text { First admission } \\
\text { (Right Blalock op.) }\end{array}$ & $\begin{array}{l}\text { Second admission } \\
\text { (Corrective surg.) }\end{array}$ & At discharge \\
\hline Blood pressure $(\mathrm{mmHg})$ & $180-138$ & $190-80$ & $168-85$ \\
\hline \multicolumn{4}{|l|}{ Hematologic study } \\
\hline RBC $\left(\times 10^{4}\right)$ & 746 & 448 & 379 \\
\hline $\mathrm{Hb}(\mathrm{Gm} / 100 \mathrm{ml})$ & 21 & 16.1 & 12.5 \\
\hline Het $(\%)$ & 67 & 48.5 & 36 \\
\hline WBC & 4,700 & 7,800 & \\
\hline \multicolumn{4}{|l|}{ Urinalysis } \\
\hline Alubstix for albumin & $(+-\#)$ & $(-)$ & $(-)$ \\
\hline Sediment & Normal & Normal & Normal \\
\hline \multicolumn{4}{|l|}{ Other tests } \\
\hline BUN (mg/100 ml) & 17.6 & & \\
\hline PSP $(15 \mathrm{~min})$ & $30.5 \%$ & & \\
\hline GRP & $(-)$ & & \\
\hline ASL-O (Todd) & 125 & & \\
\hline Urinary VMA & $(-)$ & & \\
\hline Regitin test & $(-)$ & & \\
\hline Histamin test & $(-)$ & & \\
\hline Renogram & Normal & & \\
\hline Pneumoretroperitoneum & Normal & & \\
\hline Renal angiogram & Normal & & \\
\hline
\end{tabular}

tive day uneventfully.

Comment:

In this case, family history might be important for this peculiar course of hypertension following Blalock operation. This experience is also impressive to give a clue in considering the patient with hypertension to operate upon for a few hours under extracorporeal bypass (controlled shock).

Case 3: 30-year-old female.

She was found to have congenital heart disease soon after her birth because of cyanosis and suffered from squatting after a short distance walk even in her junior high school days. During these periods she was diagnosed to be tetralogy of Fallot in the outpatient clinic of the other University hospital. At the age of 23 , in addition to palpitation and edema, she was found to have hypertension with systolic pressure of over $200 \mathrm{mmHg}$ and treated temporarily by antihypertensive drugs without desirable effect.

In the same year, she had Blalock operation. Since then her condition improved except for occasional bouts of palpitation. At the age of 28, during dancing, she suddenly experienced dizziness, nausea and vomiting which was ameliorated gradually, but headache aggravated reversely. She visited the outpatient clinic with complaints of palpitation and a sensation of compression over the anterior chest wall.

At the lst admission, the patient was cyanotic and accompanied by clubbed fingers. 


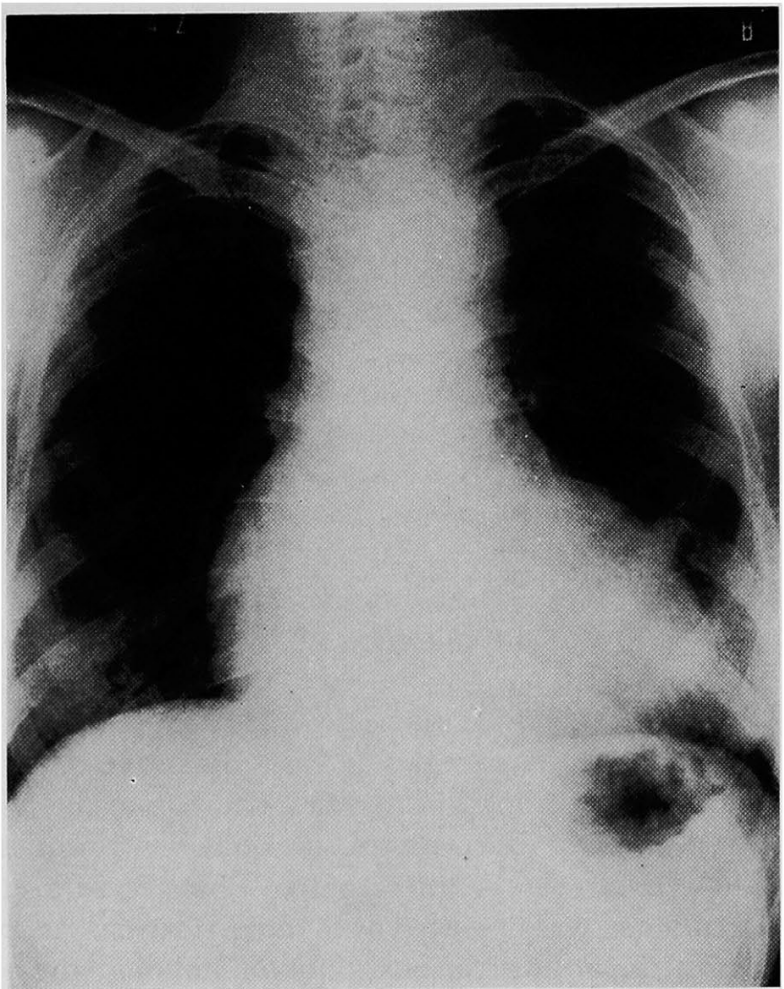

Fig. 2. Chest X-ray film of Case 3, indicating the presence of calcification in the aortic knob, concaved pulmonary artery segment, and fairly developed hilar and pulmonary vascular markings.

Table IX. Case 3: 30-year-old female

\begin{tabular}{l|c|c}
\hline & $\begin{array}{c}\text { First and second admission } \\
\text { (Exam. for op. indication) }\end{array}$ & $\begin{array}{c}\text { Third admission } \\
\text { (Corrective surg.) }\end{array}$ \\
\hline $\begin{array}{l}\text { Blood pressure }(\mathrm{mmHg}) \\
\text { Hematologic study }\end{array}$ & $205-132$ & $178-116$ \\
RBC $\left(\times 10^{4}\right)$ & 710 & 642 \\
Hb $(\mathrm{Gm} / 100 \mathrm{ml})$ & 18.7 & 17.5 \\
Hct $(\%)$ & 64 & 65.5 \\
WBC & 4,900 & 3,800 \\
Urinalysis & $(+)$ & $(+)$ \\
Alubstix for albumin & Normal & brief RBC and WBC \\
Sediment & 32.8 & 24.4 \\
Other tests & $15.5 \%$ & $32.5 \%$ \\
NPN (mg/100 ml) & &
\end{tabular}


On auscultation, grade 3-4 systolic murmur in the 4th intercostal space along the left sternal border and shunt murmur of Blalock operation in the 2nd intercostal space on the left were audible. ECG showed electric axis of $+135^{\circ}$ and biventricular hypertrophy with more prevalence of that of the right ventricle. Chest X-ray film revealed cardiac shadow compatible with tetralogy of Fallot and almost normal peripheral pulmonary vascularities. Calcification of the aorta also was demonstrable (Fig. 2). Results of tests are shown in the Table IX. The cause of dizziness and headache was attributed to vascular disorders of brain stem.

Shunt murmur of the previous Blalock operation disappeared during visits to the outpatient clinic after the lst admission. It was 7 years after the operation. With the purpose to investigate the cause of hypertension and the possibility of radical operation, the patient was re-admitted. Results of chemical tests are in the Table VIII. After discharge from the 2nd admission, she suffered from severe nasal bleeding and resultant hypotension which she was able to tolerate well. Blood pressure of systolic $120 \mathrm{mmHg}$ continued for a while, but no damage to the brain, heart and kidney was recognized. Because of well-tolerated episode of hypotension, corrective surgery was attempted and performed at the 3rd admission. During operation, marked tortuosity and calcification of the right coronary artery were found. The patient expired on the 2nd postoperative day. Gross anatomic findings of the postmortem examination revealed $550 \mathrm{Gm}$ of the heart with marked hypertrophy of both ventricles, especially of the right ventricle, and the aorta and coronary arteries showed advanced atheromatous changes with calcification. Besides, hemorrhagic tendency was observed over the pericardial sac, pleural cavity etc. As microscopic findings including various kinds of staining, the wall of the aorta revealed deposits of cholesterin crystals and fats (Figs. 3 and 4), and in the kidney

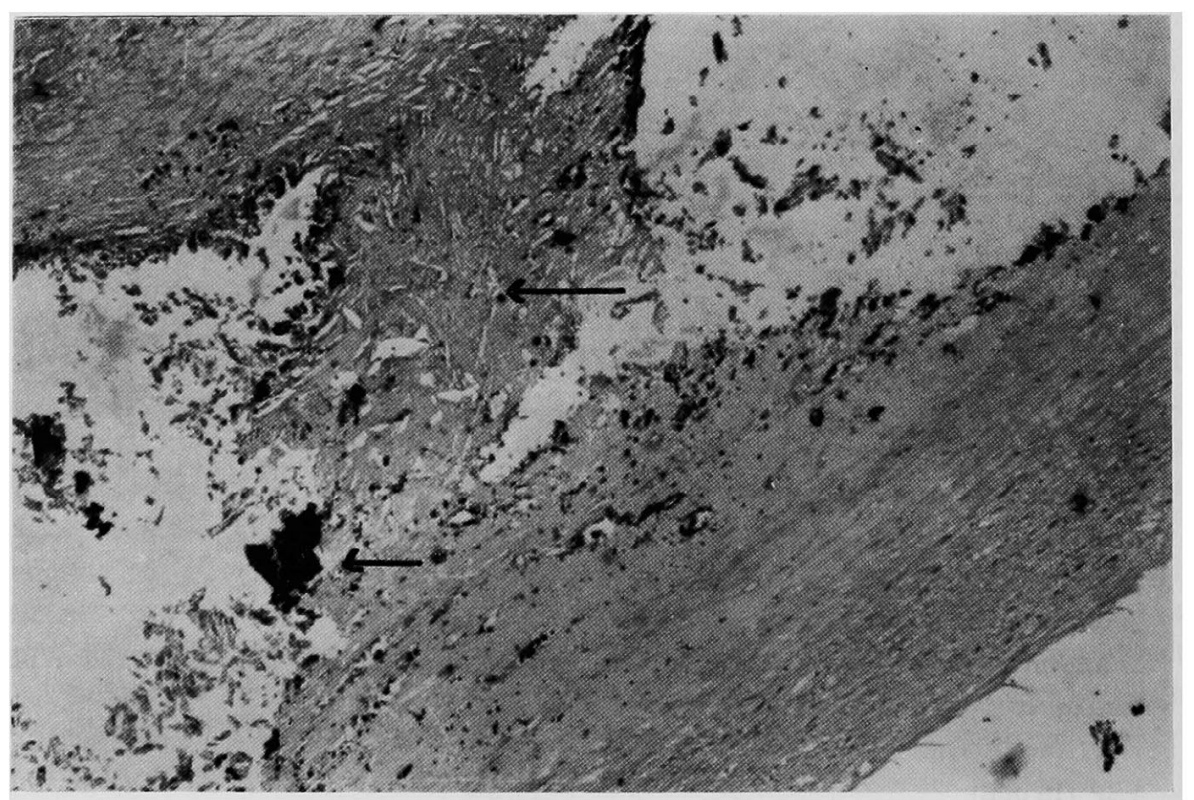

Fig. 3. Histologic section of the aortic wall in Case 3 shows deposit of cholesterin crystals and calcium inside the intima. (Hematoxylin and eosin: orig. mag. $\times 40$ ) 
simultaneous enlargement, congestion, cellular proliferation and hyalinization of the glomeruli were marked and indicated the presence of their sclerosis (Fig. 5).

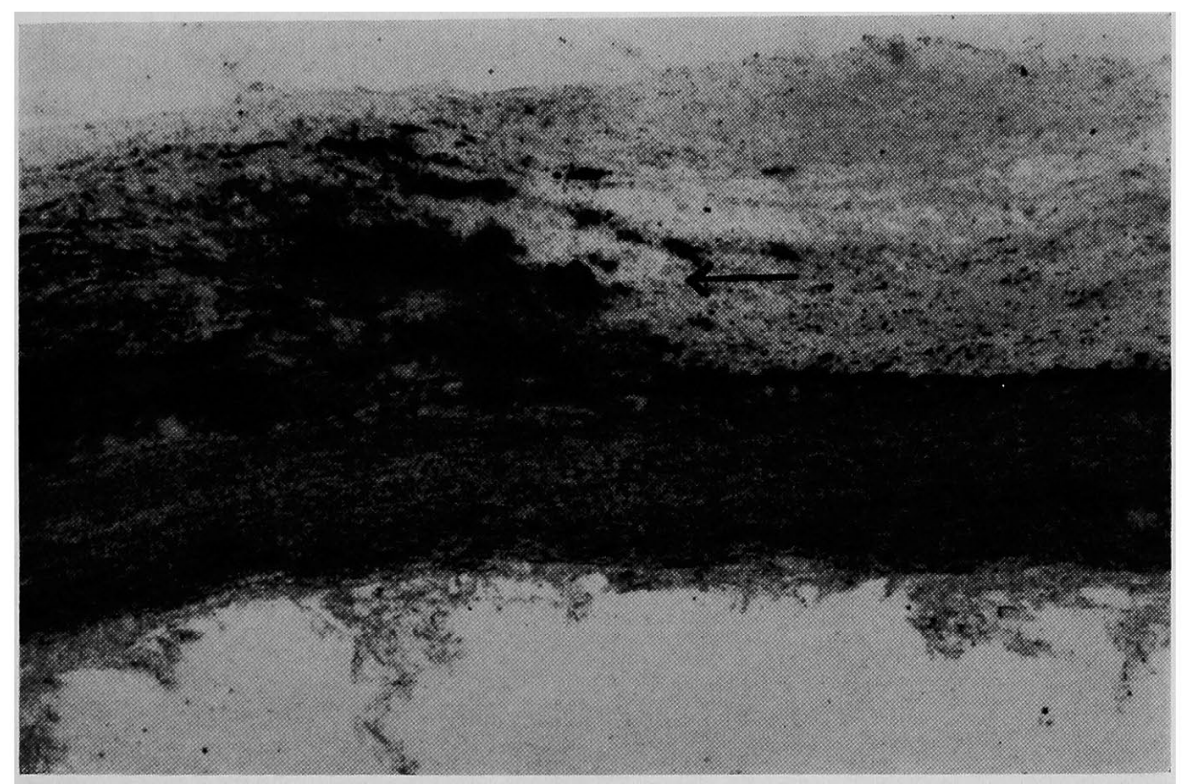

Fig. 4. Microphotograph revealing massive deposit of fat in the intima of the aorta in Case 3. (Suddan III : orig. mag. $\times 12$ )

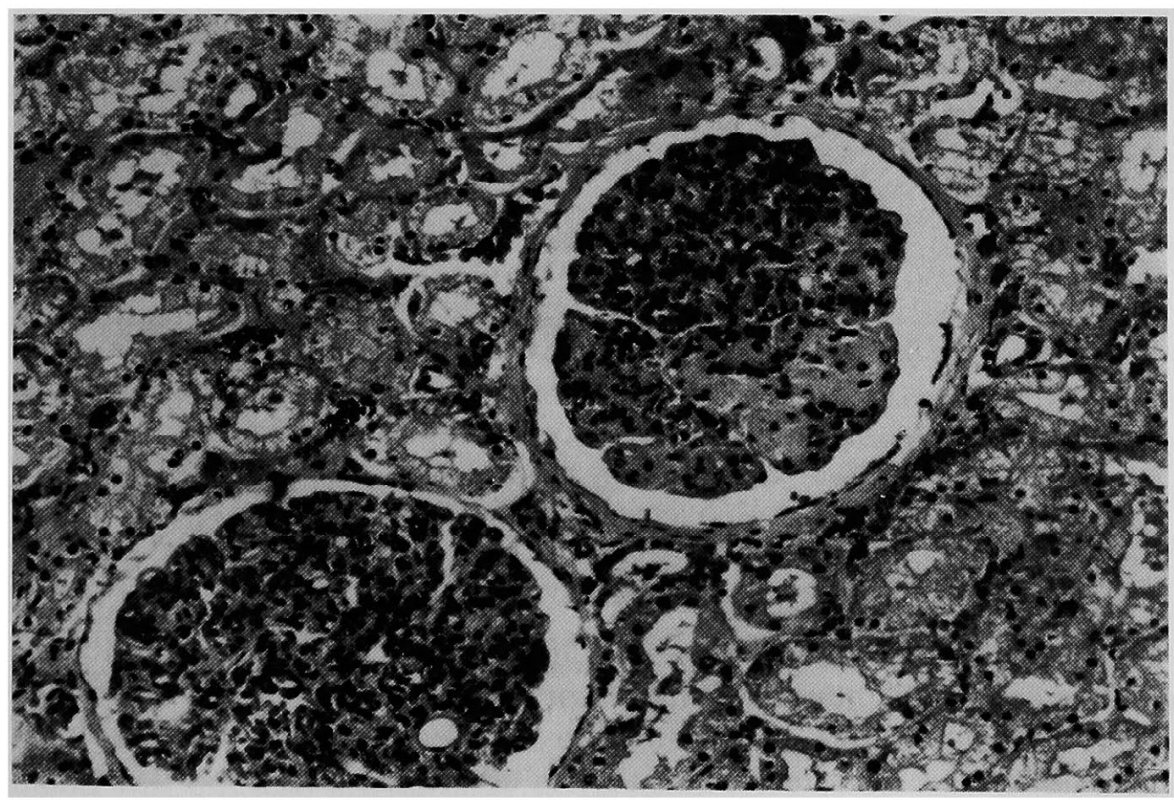

Fig. 5. Enlarged glomeruli with hypercellularity and hyaline degeneration in the kidney. (Hematoxylin and eosin: orig. mag. $\times 100$ ) 
Table X. Case 4: 10-year-old male

\begin{tabular}{l|c|c}
\hline & First admission & At discharge \\
\hline Blood pressure $(\mathrm{mmHg})$ & $144-100$ & $100-70$ \\
Hematologic study & & 562 \\
RBC $\left(\times 10^{4}\right)$ & 847 & 56 \\
Hb $(\mathrm{Gm} / 100 \mathrm{ml})$ & 25 & 8,600 \\
Hct $(\%)$ & 77 & $(-)$ \\
WBC & 5,800 & Normal \\
Urinalysis & $($ HI) \\
Alubstix for albumin & Multiple RBC \\
Sediment & & \\
Other tests & 14.5 & \\
NPN (mg/100 ml) & $32.5 \%$ & \\
PSP (15 min) & & \\
\hline
\end{tabular}

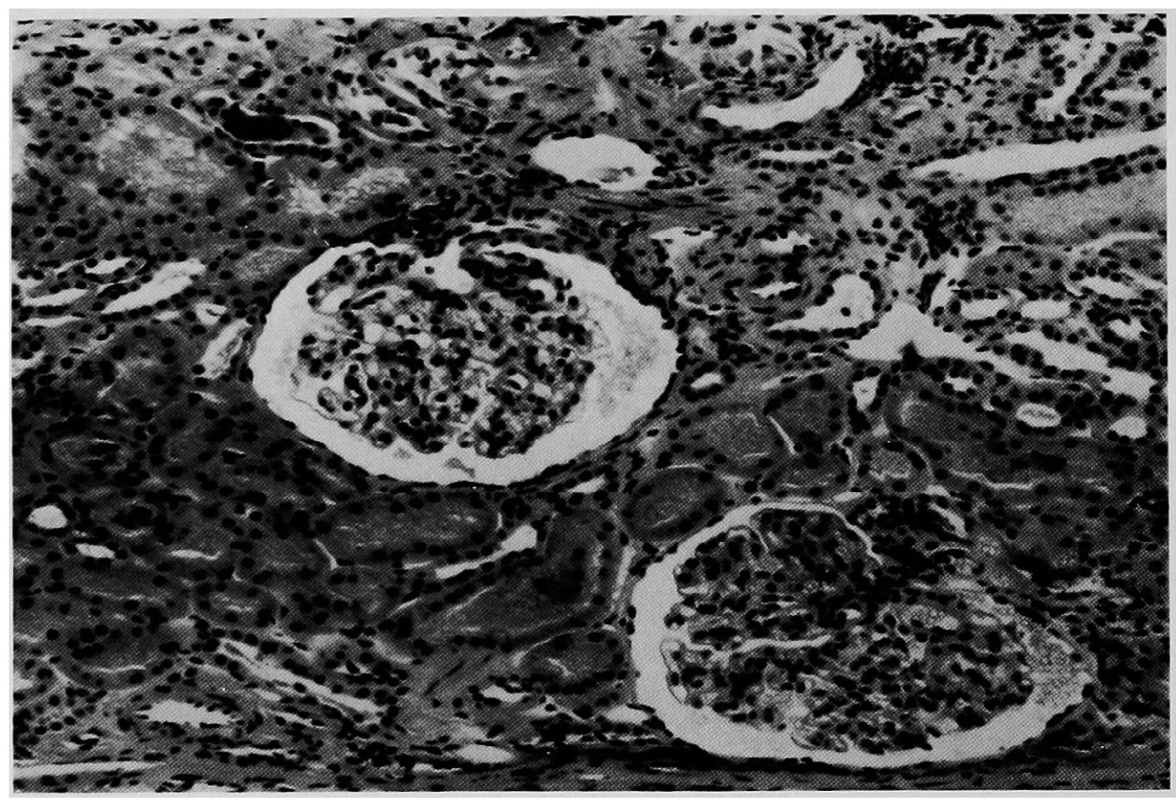

Fig. 6. Histologic section of renal biopsy of a 10-year-old boy, demonstrating enlarged glomeruli for his age with capillary dilatations and slight hypercellularity, and red blood cells and eosinophic substances inside the enlarged capsules. (Hematoxylin and eosin: orig. mag. $\times 100$ )

\section{Comment:}

This case is in advanced age for tetralogy of Fallot, and concomitant high $\mathrm{Hb}-$ content, hypertension and positive urinary protein revealed many problems to decide operative indication, although relationship between macro- and microscopic findings in autopsy and the cause of death was difficult to estimate. These findings were the most advanced stage to consider the pathophysiology of tetralogy of Fallot.

Case 4: 10-year-old male. 
The patient was found to have cyanosis soon after birth. At the age of 8 , he was diagnosed to be tetralogy of Fallot. During these periods, cyanosis increased gradually and squatting was resulted following short distance walk. At the admission to the University Hospital, he was cyanotic with clubbed fingers. On auscultation, grade 4 systolic murmur was audible in the 3 rd to 4 th intercostal space along the left sternal border. Thrill was also palpable over the same area. Second sound accentuated, ECG revealed right electric axis deviation $\left(+120^{\circ}\right)$, P-pulmonale and RVH. Chest X-ray film showed concaved pulmonary segment of cardiac shadow and usual pulmonary vascular markings. Results of various examination are summarized in the Table X.

From the previous experiences as to this situation, primary corrective surgery was attempted and carried out in February of 1971. Postoperative course was uneventful and the patient was discharged on the 32nd postoperative day.

Comment:

This is a case which was operated upon after this investigation, and also valuable to decide primary corrective surgery even under the situation accompanied by high $\mathrm{Hb}$-content, hypertension and urinary protein at this range of the age.

Further pre- and postoperative morphological comparisons of the kidney by renal biopsy will be presented in other paper (Fig. 6).

\section{Discussion}

The progression of surgical treatment for tetralogy of Fallot has been striking, however, to improve its operative results, various conditions accompanied by the disease should be understood. Pathophysiology of the disease is dependent on chronic metabolic disturbance of the tissue due to chronic oxygen deficit and on an effect of blood stasis secondary to an increase of circulating blood volume and polycythemia, basing on primary consequence of a decreased pulmonary blood flow with arteriovenous blood mixture at the level of the ventricles. Accordingly, to consider hypertension under this condition, a level of polycythemia or Hb-content, its duration and pathologic changes of the kidney, as the mostly related organ to blood pressure, should be minded.

In this paper, we used $18 \mathrm{Gm} / 100 \mathrm{ml}$ of $\mathrm{Hb}$-content as an indicator of polycythemia because of its adequate value as a standard in discussing operative mortality of the disease and in expressing its severity of the disease from surgical point of view. ${ }^{1)}$ As to hypertension, although various factors such as age, sex etc should be considered, we chose value over 140 and/or $90 \mathrm{mmHg}$ as respective systolic and diastolic pressure.

An increase of the erythrocyte count in association with hypertension has been recognized since Gaisboeck's description on polycythemia hypertonica in 1922.2) However, the cause of hypertension was not clarified and viscosity of the blood was not also attributable to its cause because of no definite relation of a level of hypertension to an increased Ht. On the other hand, Lawren and 
Berlin $^{3)}$ pointed out the presence of polycythemia secondary to dehydration to any causes and psychosomatic stresses, and it was called "stress polycythemia ", "benign polycythemia", and "relative" or "pseudo-polycythemia ".4-6) Accompanied hypertension in this condition was also unable to clarify its nature.

Tarazi et $\mathrm{al}^{4}$ ) suggested a possible etiologic relation between renal vascular hypertension and polycythemia due to renal vascular lesions basing on the renal origin of both erythropoietin and renin. McKee et $\mathrm{al}^{8)}$ on one hand, showed that hypertension was not a precursor to the development of erythrocytosis, either as a result of renal vascular damage or plasma volume depletion, but blood $\mathrm{Hb}$-content appeared to be a significant contributor to the development of hypertension. Replogle and Merrill, ${ }^{9)}$ through experimentally induced normovolemic polycythemia rasing the value of $\mathrm{Ht}$ from $38 \%$ to $60.5 \%$, was unable to produce hypertension, however, revealed the effects of polycythemia upon metabolism of cells and hemodynamics physiologically. As being supposed from descriptions above, no exact cause-and-effect relationship between polycythemia and hypertension can be clarified and more complicated mechanism to produce hypertension may be acting on cases of tetralogy of Fallot. From the point of renal structures in cyanotic congenital heart diseases, Imai, ${ }^{10}{ }^{111}$ stressing its relation to age distributions at death, classified glomerular alteration into 3 stages; 1) ectasis of the glomerular capillaries below the age of 5 years, 2) glomerular enlargement, degenerative changes of capillary walls, and proliferation and swelling of the mesangium at the age of 5 to 10 years, and 3 ) glomerular sclerosis over the age of 20 years. Case 3 of our experiences was a 30-year-old female and revealed glomerular sclerosis, calcification and atheromatous changes of the aorta and coronary arteries. Case 4 of a 10-year-old boy also exhibited proliferation of the mesangium nuclei in concomitant with fibrin thrombus in the glomerular capillaries by renal biopsy.

In our series of 111 cases of tetralogy of Fallot, 30 cases with over $18 \mathrm{Gm} /$ $100 \mathrm{ml}$ of $\mathrm{Hb}$-content in group 1 included 8 hypertensive patients $(28 \%$ ), but only 4 of the remaining 55 cases with below $18 \mathrm{Gm} / 100 \mathrm{ml}$ of $\mathrm{Hb}$-content were hypertensive $(7.3 \%)$. However, 5 out of 16 cases with high $\mathrm{Hb}$-content were hypertensive in group 2, and in the remaining 10 cases without high Hb-content, no hypertension in cases with high Hb-content was clinically apparent.

It has been reported that slight urinary protein was occasionally recognized in patients with cyanotic congenital heart disease and pathologic changes were always associated with positive urinary protein. In this series, 3 conditions-high $\mathrm{Hb}$-content, hypertension and positive urinary protein- 
will be estimated to occur in a patient at about the age of 10 years with tetralogy of Fallot.

Through this investigation, final results obtained in the group 1 and 2 clearly indicated that Blalock operation was preferable to improve high $\mathrm{Hb}$ content and hypertension, however, present clinical observation alone could not give an active clue to perform Blalock operation because of continuous progression in open-heart surgery. That is, for example, a 10-year-old boy with renal biopsy underwent corrective surgery primarily, and was normotensive of $100-70 \mathrm{mmHg}$ with negative urinary protein and normal sediment 2 weeks postoperatively. The fact showed possibly that at this age, anatomic abnormalities over the outflow tract of the right ventricle will be more important to the prognosis of tetralogy of Fallot than pathophysiology expressed as hypertension in this series.

Accordingly, from point of operative indication for tetralogy of Fallot, hypertension itself will not be decisive, however, its various effects including an especial relation to the kidney and age upon the disease should be considered as discussed in this paper.

In addition, renal biopsy will be a powerful mean to understand the effects of palliative or corrective surgery for tetralogy of Fallot on the kidney of the cyanotic patients and also should be utilized to investigate the reversibility of the renal structures following operations.

\section{REFERENCES}

1. Leachman RD, Hallman GL, Cooley DA: Circulation 32: 65, 1965

2. Gaisboeck F: Ergebn inn Med u Kinderh 21: 204, 1922

3. Lawrence JH, Berlin NI: J Biol and Med 24: 498, 1951

4. Kaung DT, Peterson RE: Arch Intern Med 110: 102, 1962

5. Russell RP, Conley CL: Arch Intern Med 114: 734, 1964

6. Hall CA: Arch Intern Med 116: 4, 1965

7. Trazi RC, Frohlich ED, Dustan HP, Gifford RW Jr, Page IH: Am J Cardiol 18: 855, 1966

8. McKee PA, Kannel WB, McNamara PM: Circulation 36: 178, 1967 (Suppl 2)

9. Replogle FL, Merrill EW: J Thorac Cardiovas Surg 60: 582, 1970

10. Iami M: J Tokyo Women's Med College 30: 149, 1960 (in Japanese)

11. Imai M: Acta Path Jap 13: 43, 1963 